\title{
FORMATION OF FUNCTIONAL LITERACY OF STUDENTS
}

\author{
Zhanar Eskazinova, Aliya Arystanbekova
}

\author{
E.A. Buketov Karaganda university, Karaganda, Kazakhstan
}

ORCID ID: 0000-0001-8307-9014

\begin{abstract}
The article considers the issues of teachers' development and training and ways of increasing their and their students' functional literacy that is seen as an indicator of mastering the competencies required in education. The authors explore methods of develop teachers and students' ability to conduct joint search for solutions to current problems and meet modern challenges in real life situations, which determines practical and theoretical significance of the research. The article aims to study the development of functional literacy of school and university students, changes in teaching methods and ways of improving skills of a modern teacher in a comprehensive school and teaching staff at a pedagogical university.
\end{abstract}

\section{INTRODUCTION}

Professional literature (domestic and foreign) states several types of functional literacy, depending on the perspective taken, i.e. what is taken as a basis of classification: literacy of school youngsters and adult literacy, reading literacy, lexical literacy, media literacy, computer literacy, science, research, IT literacy and so on.

Literacy in the modern society is a process; the preservation and development of literacy lasts through a lifetime - social changes always bring new and different demands for literacy. The level and quality of one's literacy are affected by innate and acquired abilities, different skills s/he owns, environment, way of acquiring and developing these skills through the educational system, the level of economic, technological and cultural development of society and the like. It is known that, after the children acquire basic literacy, the first condition of preserving and improving their own literacy is to continually read - develop and improve reading skills. Development of reading skills is not a task for only the initial teaching of reading, but a skill that requires special effort and investment by both teachers and students throughout the schooling. Reading becomes demanding, with subject that is constantly expanding and becoming more diverse and more complex - as students get older: reading of various literary and artistic texts, reading non-artistic texts for different purposes, informative reading in different situations, reading for personal pleasure, interpretative and expressive reading, learning by reading - reading as a lifestyle, as one of the most complex forms of human social behavior and of course, after reading - comes the writing, as a productive skill, as a need and as creativity [Grossman, 2010].

Researchers in this field around the world are dealing with the process of reading: starting with the recognition of characters and their organization into words, word sequences into sentences, the problems that occur in these phases, ending with the different ways of studying and interpreting the text. Modern societies around the world, at least nominally, are showing interest in improving the literacy, i.e. care for the poor results in national and international tests literacy. Alarmingly, the interest in reading is declining, the majority of school age children are more interested in other kinds of fun - moreover, they asses reading, and especially home reading, as an additional burden, etc. in most European countries there are national bodies to coordinate and support activities that promote reading, developing specific strategies to improve these skills [EACEA P9 Eurydice, 2011]. The downfall of functional literacy in a country is for a concern. That is why this area calls for educational reforms, and changes in curricula that define the instruction process in schools. 


\section{EDUCATIONAL PROCESS}

The lesson was and still is the main element of the educational process. The most important issue of concern to all teachers, is to increase the effectiveness of the lesson as the main form of training and education of students. The reasons for the fall of the level of students' knowledge of a foreign language is, without a doubt, the imperfection of provisioning methodology lesson, the student is a passive viewer, and central point of the monologue of the teacher. The so-called poll of some more advanced students is also not particularly active individual students class, although it is known that the lesson of a foreign language provides for communication in the classroom. We are talking about the ability of teachers to communicate with their students in a foreign language in such a way as to make every lesson interesting and informative. On the ability of teachers to communicate with students in the classroom and outside of it depends moral and psychological climate in the classroom, students' assimilation of spiritual values and moral standards, passion for science, the mood of 21 teachers and students, their mental health, the level of individual creative development.

Discipline in the modern educational process acts as the subject of self-development and a variety of activities [Erusalimov et al, 2021]. To implement the learner - centered approach to teaching and teacher education students must learn to stimulate the activity of students, to inspire them to not only understand what was expected of them, but took the position of the teacher, agreed with her, could put forward their own ideas, defend their opinions and to act as full partners in communication [McCarthy, 2005].

\section{COMMITMENT TO BUILDING STUDENT MOTIVATION FOR READING}

The PISA project developed the following definition of reading literacy: understanding, using, and reflecting on written texts, in order to achieve one's goals, to develop one's knowledge and potential, and to participate in society. [Kirsh et al, 2002; OECD, 2010]. This definition of literacy makes it obvious that the reading is not viewed as a unitary skill; rather, it is part of the process, approaches and skills that vary depending on the reader, text type, as well as on the aim or a situation in which the reading happens [Campbell et al, 2001]. Cognitive understandings that emphasize the interactive nature of the reading process and constructivist, creative nature of the process of understanding, are the concept of Reading Literacy on which the PISA project is based. The meaning of the text is constructed in reader-text interaction, and what the reader brings in that interaction are the cognitive and metacognitive strategies of text processing.

Functional literacy of pupils is supposed to give learners a chance to gain a realistic experience both at study and life activity. So many students in our country left schools after learning the English language, but still unable to speak it. The process of studying foreign language often involves five steps:

1. doing something;

2. recalling what happened;

3. reflecting on that;

4. drawing conclusions from that reflection;

5. using those conclusions to use in further practice.

It is essential that during these steps of work information, feedback, guidance and support from teacher, peers and even parents may come in, but what is crucial in forming functional literacy of pupils is that they must do most of the tasks by themselves. Main fundamental assumption on this issue is that students are able to learn more by doing things themselves rather than being told about them or how to do them. Another thing is that students come to be fully functioning young people with their 6 own life experience, their wishes and desires, their dreams, their worries, their home background, their moods, but not simply receptacles for passed-on - knowledge. Given the opportunities, they will be able to make own decisions, become more responsible for their learning. Priorities of new approaches in teaching English are the possibility that students can use their early learning experience with the use while studying new. Let's make some discourse in existing teaching 
methods. Generally, a method is the way teachers' activity. They may choose methods on the base of what approach they follow. According to Jim Scrivener, there is a range of well-known methods and approaches:

- the grammar-translation method;

- the audio-lingual method;

- communicative language teaching;

- total physical response;

- community language learning;

- the natural approach;

- task-based learning;

- the silent way;

- person- centred approaches [Formation of functional literacy of 12-year school students in English. Methodological instructions. - Astana: National academy of education named after Y. Altynsarin NAE, 2013. - 38 p.].

\section{LITERACY PRINCIPLES}

To be more effective literacy trainer it is necessary to abandon the notion that there is one correct way to do things, and that way is to be found in the standard course books. If you devise your own methods and your own content, based upon local needs, interests, characteristics and conditions, (functional) your approach will be more meaningful to both you and learners. The principles listed here rather than copy what others have done: both content and method. The principle invoked by orthodoxy is "This is the way it has always been done," or "This is the "proper' way to do it," is merely that it is based upon tradition rather than on function. In your search for identifying words and sentences that are immediately useful, you must abandon standard text books which list words and sentences that may have been relevant to other communities.

Let your learners struggle a little bit; what they learn they will memorize better. Do not force them to struggle so hard that they will give up; but find ways to let them say, "We did it ourselves." [Formation of functional literacy of 12-year school students in English. Methodological instructions. - Astana: National academy of education named after Y. Altynsarin NAE, 2013. - 38 p].

\section{SPECIFIC FEATURES OF FUNCTIONAL LITERACY}

At the same time, the research findings point to the need for changes in general education and teacher training at universities. It is obvious that modern approaches and the corresponding interactive methods that are insufficiently used in modern education, both at school and in a university teacher training course, have an important role in the development of functional literacy. Subject knowledge should be flexible, deep and well-mastered, as this is a prerequisite for the formation of the functional literacy of learners as the integral characteristic of their personality, their ability to take a public stance in a certain activity and science. At present, functional literacy is the first step for successful selfrealization in society.

Specific features of functional literacy:

- focus on solving social and everyday problems;

- situational characteristics of the personality which reveal themselves in certain social circumstances;

- a link to solving standard, typical tasks;

- mastery of a certain elementary (basic) level of reading and writing skills;

- is primarily used to assess adults;

- is relevant mainly in the context of finding efficient ways to increase literacy.

Within the system of training and career development of school and university teachers, the following conditions should be created: 
- an integrated approach to teachers training aimed at preparing them to develop functional literacy of students;

- mastery of subject content, modern teaching methods and techniques;

- teaching methods and techniques are applied in accordance with the goal;

- conducting students' research projects;

- taking into account individual needs, interests and aptitudes of students;

- organizing the work of the teams of teachers under the supervision of their organization, professional associations and unions;

- facilitating the use of digital resources in education and information systems to assess the development of each student;

- design, planning and management of the educational environment in cooperation with other teachers and partners;

- after action review and making necessary adjustments.

Thus, functional literacy is a meta-subjective, integral phenomenon that is formed in the course of studying school subjects with focus on personal features and that is manifested in various forms. [Development of functional literacy of school and university students. Shalashova, Shevchenko, Makhotin, 2017].

\section{DISCUSSION}

Having examined the questionnaires of teachers and students at school and university, the authors could describe the current state of functional literacy in school and teacher training university and ways of its development. Practices of teaching school teachers teams should include situations related to solving relevant pedagogical problems, including the use of technologies for the development of functional literacy of students. During training, teachers should think over and discuss the continuity of the content and stages of the development of various components that make up functional literacy.

From our point of view, the crucial among the considered conditions is the need to train school teams of teachers to develop certain competencies. This practice has been implemented since 2013 in the Moscow City Teachers' Training University as the main form of advanced teachers training. Over the period from 2015 to 2017, the total of 1,020 educators from 43 Moscow schools have upgraded their qualifications within this program [Shalashova, Shevchenko, Makhotin, 2017]. This form of training teachers becomes more and more demanded among heads of educational organizations who see it as an effective tool for the development of functional literacy of both teachers and students [Shalashova, Shevchenko, 2015, 2016].

\section{CONCLUSIONS}

A learner who is 'functional' in English is able to consider a problem or task, identify the functional English skills that will help them to tackle it, select from the range of skills in which they are competent (or know what help they need and who to ask), and apply them appropriately. This interplay of the four factors means, for example, that tackling a complex problem in a situation with which a learner is unfamiliar but that requires relatively undemanding English skills may involve a higher level of 'functionality' than a relatively straightforward task in a familiar context that requires more advanced 'subject' skills. It is the combination of the four factors that confirms the functional skill level. The purpose of education is not to produce knowledge, and to teach students to use those tools that will help them to generate the knowledge needed to solve a variety of problem situations in personal, social and professional activities.

The conclusions resulting from the application of this teaching method show that it provides the enhancement of the knowledge and skills necessary to create texts of various types, thereby contributing to the development of functional literacy among students. 


\section{REFERENCE:}

Campbell et al, 2001.

Development of functional literacy of school and university students. Shalashova, M.M., Shevchenko N.I., Makhotin, D.A., 2017.

Erusalimov, R., Stoykova, P., Nestorov, L., Panteleeva, I., Marinov, M. (2021). Increasing the financial literacy and economic culture of students in grades 5-10. ISBN 978-954-23-1948-1, D.A. Tsenov Academy of Economics, Svishtov

Formation of functional literacy of 12-year school students in English. Methodological instructions. - Astana: National academy of education named after Y. Altynsarin NAE, 2013. - 38 p.

Kirsh et al, 2002; OECD, 2010.

McCarthy, M., O’Dell, F. English collocations in use. Cambridge University Press, 2005. - 190p.

Rudik, G.A., Zhaytapova, A.A. [2014]. Functional Literacy in Reading: Workbookfor Self-study and Reliable Assessment.

Shalashova, M.M., Shevchenko N.I., Makhotin, D.A. [2017]. Training Teachers to Implement GSES of General Education: New Models of Teacher Training [Training of School Teams]. Moscow: Moscow State Teachers' Training University.

Shalashova, M.M., Shevchenko, N.I. [2015]. The quality of continuing vocational programs: the search for answers to the challenges of our time, Human Capital, 7[79], 94-98.

Shalashova, M.M., Shevchenko, N.I. [2016]. Corporate model of professional development: training school teams of teachers to implement GSES of General Education, Bulletin of the Moscow State Regional University. Pedagogy Series, 2, 179-189. 